\title{
Mansoura Journal of Forensic Medicine and Clinical Toxicology
}

\section{ECG Changes as Predictor of Mortality and Major Outcome Events in Theophylline Acutely Intoxicated Patients}

\author{
Arwa A. Abuelfadl; Marwa M. Shahin; Ghada M. Alghazaly
}

\begin{abstract}
KEYWORDS

Acute

Theophylline toxicity

Electrocardiography

Changes

QTc

Mortality

Ventilation

ICU

Admission

Hemodialysis

Acute theophylline toxicity is still an important cause of intoxication with major consequences; significant morbidity and mortality. Conflicting reports about both age and serum theophylline concentrations as predictors for development of major toxic effects were suggested by many authors. However, little is known about electrocardiography (ECG) as predictor of mortality and major outcome events in acute theophylline poisoned patients. The current observational cross sectional study was conducted to evaluate electrocardiographic findings as predictor of mortality and major outcome events [intensive care unit (ICU) admission, need for mechanical ventilation and need for hemodialysis] in acute theophylline toxicity. Twenty eight adult patients acutely exposed to theophylline have participated in the study. The severity of symptoms and signs of acute theophylline poisoning was graded into mild, moderate and severe grade theophylline poisoning. Electrocardiography was recorded and analyzed for rate, rhythm, axis, voltage, $S T$ and $T$ wave abnormalities, conduction defects, PR interval. The ECG changes induced by acute theophylline poisoning were graded into minor, moderate and severe. Corrected QT interval (QTc) was estimated according to Bazett's formula; $Q T c=Q T / \sqrt{R R}$. Both normal and severe ECG changes were recorded in seven $(25 \%)$ patients each. Meanwhile, moderate ECG changes were verified in $14(50 \%)$ of patients. Fourteen patients (50\%) showed a prolonged QTe interval. Grading of ECG changes revealed significant statistical association with theophylline poisoning severity, theophylline level and major outcome events (ICU admission and need for hemodialysis). Meanwhile, no significant statistical association was perceived between QTe interval and any of sociodemographic, toxicological \& clinical data, mortality and major outcome events.
\end{abstract}

\section{Introduction}

Theophylline is a dimethylxanthine that has been used since 1950 as a bronchodilator in treatment of acute and chronic asthma. Furthermore, it is a smooth muscle relaxant, myocardial stimulant and diuretic agent (Amin, et al., 2003). Theophylline and its derivatives remain widely prescribed drugs in many

Arwa A. Abuelfadl; Marwa M. Shahin;

Forensic Medicine and Clinical Toxicology Department, Faculty of Medicine, Tanta University

Ghada M. Alghazaly

Internal Medicine Department, Faculty of Medicine, Tanta University developing countries because they are effective, inexpensive and widely available (Wu et al., 2013).

Theophylline is an important cause of intoxication with significant morbidity and mortality. Its therapeutic use may be associated with toxicity due to its narrow therapeutic index, variable individual pharmacokinetics and development of sustained release formulations. Both intentional and accidental toxicity are common due to low cost and theophylline availability in variety of over-thecounter formulations (Lim et al., 2005; Raymond, 2010). 
Theophylline intoxication may be acute, acute on therapeutic or chronic. Acute intoxication may result from single ingestion of more than $10 \mathrm{mg} / \mathrm{kg}$ of theophylline. Acute on therapeutic intoxication results from theophylline-treated patients when they ingest a toxic dose (Henry and Minton, 2011). Chronic intoxication occurs in patients receiving repeated excessive theophylline doses for 72 hours. It may also result from impaired theophylline metabolism due to use of cytochrome P-450 inhibitor drugs or associated illness (Shannon and Perry, 2005).

Theophylline exerts its toxicity through adenosine receptors antagonism, inhibition of phosphodiesterase enzyme and increasing of CAMP (Paul et al., 2010). Morbidity and mortality of theophylline toxicity are secondary to cardiovascular and CNS effects i.e. life threatening arrhythmias and hypotension as well as refractory seizures (Reilly, 2008). The exact mechanism of cardiac toxicity is still unclear. However, it might be attributed to increased circulating catecholamines and/or to cardiac adenosine receptors antagonism (Shannon, 2007).

Electrocardiographic changes in theophylline intoxication might show all types of tachy-arrhythmias including sinus tachycardia, supraventricular tachycardia (SVT), multifocal atrial tachycardia, atrial fibrillation, premature ventricular beats and ventricular tachycardia (Shannon, 2007). On the other hand, studies on electrophysiological effects of theophylline have revealed a decrease in both sinoarterial conduction time and His-Purkinje conduction interval. Inversion of $\mathrm{T}$ wave and prolongation of QT interval were also reported with severe theophylline toxicity (Kolander et al., 1989).

Predicting outcome in critically ill patients is a key component and a major concern of any health care system (Kelly et al., 2002). At the same time, acute theophylline toxicity is still a big problem with major consequences (Shannon, 2007); together with, a striking lack of recent studies regarding predictors of acute theophylline toxicity outcomes.

Hereafter, the current study aimed to use ECG changes in acute theophylline intoxication as a simple tool for prediction of mortality and major outcome events like, ICU admission, need for mechanical ventilation and need for hemodialysis.

\section{Patients and Methods}

This prospective observation cross sectional study was carried out at Poison Control Unit, Emergency Hospital, Tanta University. It was approved by the Research Ethical Committee, Faculty of Medicine, Tanta University. All participants received detailed information concerning aim of research work, and informed consent was obtained from each participant or his relatives prior to commencement of the study.

\section{Eligibility criteria:}

Over a period of eighteen months all adult patients with history and/or manifestations of acute theophylline toxicity were included.

\section{Exclusion criteria:}

1- Patients with history of cardiac diseases (rheumatic heart disease, atrioventricular arrhythmias, congestive cardiac failure, 2nd or 3rd degree heart block, abnormalities in echocardiogram and ischemic heart disease).

2- Patients who received any unreported medical treatment before admission together with patients of mixed ingestion.

3- Patients with any pre-existing chronic diseases including; hypertension, diabetes mellitus, hepatic \& renal diseases and cancer. 
Outcome measures:

Primary outcome included mortality. Meanwhile, major outcome events included, ICU admission, need for mechanical ventilation and need for hemodialysis.

Diagnosis of acute theophylline toxicity was based on history of theophylline intake and/or manifestations of acute theophylline toxicity together with estimation of serum theophylline level. A standard sheet was conducted to record complete clinical assessment of each patient. The following data were recorded for each patient:

1. Personal history: it includes name, age, gender, occupation, education, residence and marital state.

2. Past history: it includes history of chronic systemic illness (cardiac diseases, diabetes, hypertension, renal, liver, blood disease or others).

3. Pre-hospital care: if any intervention occurred before reaching the hospital.

4. Toxicological data: it includes route \& circumstances of poisoning and prehospitalization period.

5. Clinical Examination: it includes vital signs, neurological, respiratory system, cardiovascular system and gastrointestinal (GIT) examination.

The severity of symptoms and signs of acute theophylline toxicity was graded according to Lim et al. (2005) into:

- Mild grade theophylline toxicity; anorexia, nausea, vomiting, palpitations, nervousness, insomnia and tachycardia.

- Moderate grade theophylline toxicity; symptoms of mild poisoning plus wide pulse pressure, initial hypertension then hypotension, tremors, agitation and hyperthermia.

- Severe grade theophylline toxicity; symptoms of moderate poisoning plus seizures, ventricular arrhythmias, extreme hyperthermia with dehydration, sever hypotension and coma.
Blood samples were collected immediately after admission before giving any medication. Under complete aseptic conditions, $5 \mathrm{ml}$ of venous blood were taken from any easily accessible vein. Each blood sample was collected on ethylene-diamine-tetra-acetic acid (EDTA) anticoagulant and plasma was separated by centrifugation. Serum theophylline level was measured according to Sheehan and Haythorn (1976).

The disposal of blood collection syringes, tubes and body fluids (blood samples) was safely done to avoid any risk of environmental pollution. Privacy and confidentiality of patients' records and data was ascertained through coding system.

Electrocardiography was recorded on admission, every 6 hours and when an abnormality was observed on cardiac monitor. ECGs were interpreted by a cardiologist, blinded to study hypothesis and case data. The ECG was analyzed for rate, rhythm, axis, voltage, $\mathrm{ST}$ and $\mathrm{T}$ wave abnormalities, conduction defects, PR interval. Corrected QT interval (QTc) was estimated according to Bazett's formula; QTc $=\mathrm{QT} \sqrt{ } \mathrm{RR}$ (normally up to 0.44 second). Echocardiography was done as soon as possible after admission.

Electrocardiographic changes induced by acute theophylline toxicity were graded according to Poisoning Severity Score into:

- Minor; isolated extrasystoles.

- Moderate; sinus tachycardia [heart rate (HR) $\sim 140-180$ in adults], frequent extrasystoles, atrial fibrillation/flutter, atrioventricular (AV)-block I-II, prolonged QRS and QTc-time, repolarization abnormalities, myocardial ischemia.

- Severe; severe sinus bradycardia (HR $\sim 40$ in adults), severe sinus tachycardia (HR $\sim 180$ in adults), life-threatening ventricular dysrhythmias, AV block III, asystole, myocardial infarction (Persson et al, 1998). 
Data were collected and entered to the computer using SPSS (Statistical Package for Social Science) program for statistical analysis (version 20). Data were entered as numerical or categorical, as appropriate. KolmogorovSmirnov (D) test was used to test normality of the distribution of variables, non-parametric statistics (minimum and maximum, median and Inter-quartile range) were adopted even when KS test was significant, and comparison using Kruskal-Wallis test was used to test several independent samples, Jonckheere-Terpstra test to test for median against ordered alternatives, and Mann-Whitney U test was used to test two independent samples. Chi-Squared test (MonteCarlo corrected) for NxM table (Terpstra, 1952; Jonckheere, 1954a; Jonckheere, 1954b; Field, 2006).

\section{Results}

During the study period, twenty eight patients have fulfilled the eligibility criteria and have accepted study participation. Their ages ranged between 18 and 32 years $(20.96 \pm 4.29)$; of them females represented 27 patients $(96.43 \%)$ and males represented one patient $(3.57 \%)$. Nineteen patients $(67.86 \%)$ were single, 16 patients $(57.14 \%)$ were from urban areas. Sociodemographic characteristics of the participant patients were illustrated in table (1).

Toxicological and clinical data of the participant patients are demonstrated in table (2). It revealed that, all patients were in suicidal attempts, no accidental exposure was recorded. Similarly, oral route was registered in all cases. Pre hospital period ranged between 1-12 hours with a mean value of $6.07 \pm 3.231$ hours. Mild, moderate and severe theophylline toxicity were observed in $6(21.43 \%), 14(50.00 \%)$ and 8 $(28.57 \%)$ of patients respectively. Serum theophylline level ranged between 13.10$107.30 \mathrm{mg} / \mathrm{L}$ with a mean value of $33.18 \pm 27.591 \mathrm{mg} / \mathrm{L}$.
At discharge time $27(96.43 \%)$ patients were improved, one $(3.57 \%)$ patient had died. During their hospital stay, eight $(28.57 \%)$ patients were admitted to ICU; out of them five $(17.86 \%)$ were subjected to hemodialysis, one $(3.57 \%)$ patient required intubation and mechanical ventilation assistance. Among those hemodialysed patients, one (3.57\%) patient died (Table 2).

Electrocardiographic examination revealed sinus tachycardia in 21 patients and prolonged QTc in 14 patients. In the same time, upsloping ST segment was found in four patients and biphasic $\mathrm{T}$ wave in three patients. Severe sinus tachycardia was recorded in 6 patients and premature ventricular contractions were noticed in 3 patients.

Both normal ECG and severe ECG changes were recorded in seven $(25 \%)$ patients each. Meanwhile, moderate ECG changes were verified in $14(50 \%)$ of patients (Table 2). Table (3) revealed no significant statistical association was noticed between grading of ECG changes and either sociodemographic data or pre-hospitalization period. While, both theophylline poisoning severity, theophylline level and major outcome (ICU admission and need for hemodialysis) registered significant statistical association with grading of ECG changes.

It should be noted that, seven patients out of the ICU admitted patients (8 patients) registered severe grade of ECG changes. All of the hemodialysed patients ( 5 patients) recorded severe grade of ECG changes. On the other hand, the patient who required intubation and mechanical ventilation assistance showed moderate grade of ECG changes. However, the dead patient who was admitted to ICU and underwent hemodialysis documented severe grade of ECG changes.

The studied group revealed a mean QTc interval of $0.46 \pm 0.097$ seconds (range 0.340.65 seconds) as described in table (2). Fourteen patients $(50 \%)$ showed a prolonged 
QTc interval (0.544 \pm 0.064 seconds). Mortality, ICU admission, need for ventilation and hemodialysis were noticed in patients with prolonged QTc interval rather than in patients with a normal QTc interval. However, no significant statistical association was perceived between QTc interval and any of sociodemographic, toxicologic, clinical data, mortality and major outcome events (ICU admission, need for mechanical ventilation and need for hemodialysis) as shown in table (4).

Table (1): Sociodemographic data of acute theophylline-poisoned patients $(n=28)$

\begin{tabular}{|l|l|c|c|}
\hline \multicolumn{2}{|c|}{ Characteristic variable } & $\mathbf{n}$ & $\mathbf{\%}$ \\
\hline \multirow{2}{*}{ Sex } & Males & 1 & 3.57 \\
\cline { 2 - 4 } & Females & 27 & 96.43 \\
\hline \multirow{3}{*}{ Marital status } & Single & 19 & 67.86 \\
\cline { 2 - 4 } & Married & 9 & 32.14 \\
\hline \multirow{3}{*}{ Residence } & Urban & 16 & 57.14 \\
\cline { 2 - 4 } & Rural & 12 & 42.86 \\
\hline \multirow{5}{*}{ Education } & Illiterate & 1 & 3.57 \\
\cline { 2 - 4 } & Read \& write & 7 & 25.00 \\
\cline { 2 - 4 } & Secondary school & 11 & 39.29 \\
\cline { 2 - 4 } & High education & 9 & 32.14 \\
\hline \multirow{3}{*}{ Work } & Unemployed & 2 & 7.14 \\
\cline { 2 - 4 } & Student & 11 & 39.29 \\
\cline { 2 - 4 } & Housewife & 8 & 28.57 \\
\cline { 2 - 4 } & Worker & 7 & 25.00 \\
\hline
\end{tabular}

n: number

Table (2): Toxicological and clinical data of acute theophylline-poisoned patients $(n=28)$.

\begin{tabular}{|c|c|c|c|c|}
\hline \multicolumn{3}{|c|}{ Characteristic variable } & $\mathbf{n}$ & $\%$ \\
\hline \multirow{2}{*}{ Manner of poisoning } & \multirow{2}{*}{\multicolumn{2}{|c|}{$\begin{array}{l}\text { Accidental } \\
\text { Suicidal }\end{array}$}} & 0 & 0.00 \\
\hline & & & 28 & 100.00 \\
\hline Route of poisoning & \multicolumn{2}{|l|}{ Oral } & 28 & 100.00 \\
\hline \multirow{3}{*}{ Theophylline poisoning severity } & \multicolumn{2}{|l|}{ Mild } & 6 & 21.43 \\
\hline & \multicolumn{2}{|l|}{ Moderate } & 14 & 50.00 \\
\hline & \multicolumn{2}{|l|}{ Severe } & 8 & 28.57 \\
\hline \multirow{4}{*}{ ECG severity grading } & \multicolumn{2}{|l|}{ Normal } & 7 & 25.00 \\
\hline & \multicolumn{2}{|l|}{ Mild } & 0 & 0.00 \\
\hline & \multicolumn{2}{|l|}{ Moderate } & 14 & 50.00 \\
\hline & \multicolumn{2}{|l|}{ Severe } & 7 & 25.00 \\
\hline \multirow{5}{*}{ Outcome $^{\mathrm{a}}$} & \multicolumn{2}{|c|}{ ICU admission } & 8 & 28.57 \\
\hline & \multicolumn{2}{|c|}{ Haemodialysis } & 5 & 17.86 \\
\hline & \multicolumn{2}{|c|}{ Mechanical ventilation } & 1 & 3.57 \\
\hline & \multicolumn{2}{|l|}{ Mortality } & 1 & 3.57 \\
\hline & Minimum & Maximum & $\overline{\text { Mean }}$ & $\overline{\overline{S D D}}$ \\
\hline Pre-hospitalization period (hr) & 1.00 & 12.00 & 6.07 & 3.231 \\
\hline Theophylline level (mg/L) & 13.10 & 107.30 & 33.18 & 27.591 \\
\hline QTc (sec.) & 0.34 & 0.65 & 0.46 & 0.097 \\
\hline
\end{tabular}

a: Outcome is not mutually exclusive, ECG:Electrocardiographic, n: number, SD: standard deviation 
Table (3): Monte Carlo, Kruskal-Wallis and Jonckheere-Terpstra analysis of ECG grading against sociodemographic, toxicological and clinical data $(n=28)$.

\begin{tabular}{|c|c|c|c|}
\hline \multirow{2}{*}{\multicolumn{2}{|c|}{ Characteristic variable }} & \multicolumn{2}{|c|}{ ECG severity grading } \\
\hline & & Test statistics & p value \\
\hline \multicolumn{2}{|l|}{ Age } & $\mathrm{X}_{(\mathrm{KS}) \mathrm{df}=2)}^{2}=4.928$ & $\begin{array}{l}\mathrm{p}=0.085 \mathrm{NS} \\
\mathrm{p}_{(\mathrm{JT})}=0.123 \mathrm{NS}\end{array}$ \\
\hline \multicolumn{2}{|l|}{ Sex } & $\mathrm{X}_{(\mathrm{df}=2)}^{2}=3.111$ & $\mathrm{p}_{(\mathrm{MC})}=0.499 \mathrm{NS}$ \\
\hline \multicolumn{2}{|l|}{ Marital status } & $\mathrm{X}_{(\mathrm{df}=2)}^{2}=5.404$ & $\mathrm{p}_{(\mathrm{MC})}=0.092 \mathrm{NS}$ \\
\hline \multicolumn{2}{|l|}{ Residence } & $\mathrm{X}_{(\mathrm{df}=2)}^{2}=0.875$ & $\mathrm{p}_{(\mathrm{MC})}=0.881 \mathrm{NS}$ \\
\hline \multicolumn{2}{|l|}{ Education } & $\mathrm{X}_{(\mathrm{df}=6)}^{2}=6.961$ & $\mathrm{p}_{(\mathrm{MC})}=0.336 \mathrm{NS}$ \\
\hline \multicolumn{2}{|l|}{ Work } & $\mathrm{X}_{(\mathrm{df}=6)}^{2}=6.597$ & $\mathrm{p}_{(\mathrm{MC})}=0.399 \mathrm{NS}$ \\
\hline \multicolumn{2}{|c|}{ Pre-hospitalization period (hr) } & $\mathrm{X}_{(\mathrm{KS}) \mathrm{df}=2)}^{2}=1.904$ & $\begin{array}{l}\mathrm{p}=0.386 \mathrm{NS} \\
\mathrm{p}_{(\mathrm{JT})}=0.280 \mathrm{NS}\end{array}$ \\
\hline \multicolumn{2}{|c|}{ Theophylline level } & $X_{(\mathrm{KS}) \mathrm{df}=2)}^{2}=17.515$ & $\begin{array}{l}\mathrm{p}=0.000^{*} \\
\mathrm{p}_{(\mathrm{JT})}=0.000^{*}\end{array}$ \\
\hline \multicolumn{2}{|c|}{ Theophylline poisoning severity } & $\mathrm{X}_{(\mathrm{df}=4)}^{2}=49.000$ & $\mathrm{p}_{(\mathrm{MC})}=0.000 *$ \\
\hline \multirow{4}{*}{ Major outcome $^{\mathrm{a}}$} & ICU admission & $\mathrm{X}_{(\mathrm{df}=2)}^{2}=23.450$ & $\mathrm{p}_{(\mathrm{MC})}=0.000 *$ \\
\hline & Hemodialysis & $\mathrm{X}_{(\mathrm{df}=2)}^{2}=18.261$ & $\mathrm{p}_{(\mathrm{MC})}=0.000 *$ \\
\hline & Mechanical ventilation & $\mathrm{X}_{(\mathrm{df}=2)}^{2}=1.037$ & $\mathrm{p}_{(\mathrm{MC})}=1.000 \mathrm{NS}$ \\
\hline & Mortality & $\mathrm{X}_{(\mathrm{df}=2)}^{2}=3.111$ & $\mathrm{p}_{(\mathrm{MC})}=497 \mathrm{NS}$ \\
\hline
\end{tabular}

${ }^{a}:$ Outcome is not mutually exclusive, ECG:Electrocardiographic, n: number, SD: standard deviation, df: degree of freedom, MC: Monte Carlo significance, NS: non significant difference, *: significant, KS: Kruskal-Wallis test, JT: Jonckheere-Terpstra test

Table (4): Mann-Whitney and Monte Carlo analysis of QTc against sociodemographic, toxicological and clinical data $(\mathrm{n}=28)$.

\begin{tabular}{|c|c|c|c|}
\hline \multirow{2}{*}{\multicolumn{2}{|c|}{ Characteristic variable }} & \multicolumn{2}{|c|}{$\overline{\text { QTe }}$} \\
\hline & & Test statistics & p value \\
\hline \multicolumn{2}{|l|}{ Age } & $\mathrm{Z}_{(\mathrm{MW})}=0.771$ & $\mathrm{p}=0.482 \mathrm{NS}$ \\
\hline \multicolumn{2}{|l|}{ Sex } & $\mathrm{X}_{(\mathrm{df}=1)}^{2}=1.037$ & $\mathrm{p}_{(\mathrm{MC})}=1.000 \mathrm{NS}$ \\
\hline \multicolumn{2}{|l|}{ Marital status } & $\mathrm{X}_{(\mathrm{df}=1)}^{2}=0.164$ & $\mathrm{p}_{(\mathrm{MC})}=1.000 \mathrm{NS}$ \\
\hline \multicolumn{2}{|l|}{ Residence } & $\mathrm{X}_{(\mathrm{df}=1)}^{2}=0.583$ & $\mathrm{p}=0.445 \mathrm{NS}$ \\
\hline \multicolumn{2}{|l|}{ Education } & $\mathrm{X}_{(\mathrm{df}=3)}^{2}=1.345$ & $\mathrm{p}_{(\mathrm{MC})}=1.000 \mathrm{NS}$ \\
\hline \multicolumn{2}{|l|}{ Work } & $\mathrm{X}_{(\mathrm{df}=3)}^{2}=2.234$ & $\mathrm{p}_{(\mathrm{MC})}=0.638 \mathrm{NS}$ \\
\hline \multicolumn{2}{|c|}{ Pre-hospitalization period (hr) } & $\mathrm{Z}_{(\mathrm{MW})}=1.007$ & $\mathrm{p}=0.329 \mathrm{NS}$ \\
\hline \multicolumn{2}{|c|}{ Theophylline level } & $Z_{(\mathrm{MW})}=1.271$ & $\mathrm{p}=0.227 \mathrm{NS}$ \\
\hline \multicolumn{2}{|c|}{ Theophylline poisoning severity } & $\mathrm{X}_{(\mathrm{df}=2)}=8.571$ & $\mathrm{p}_{(\mathrm{MC})}=0.013 \mathrm{NS}$ \\
\hline \multirow{4}{*}{ Major outcome $^{a}$} & ICU admission & $\mathrm{X}_{(\mathrm{df}=1)}^{2}=0.700$ & $p_{(\mathrm{MC})}=0.678 \mathrm{NS}$ \\
\hline & Hemodialysis & $\mathrm{X}_{(\mathrm{df}=1)}^{2}=2.191$ & $\mathrm{p}_{(\mathrm{MC})}=0.326 \mathrm{NS}$ \\
\hline & Mechanical ventilation & $\mathrm{X}_{(\mathrm{df}=1)}^{2}=1.037$ & $\mathrm{p}_{(\mathrm{MC})}=1.000 \mathrm{NS}$ \\
\hline & Mortality & $\mathrm{X}_{(\mathrm{df}=1)}^{2}=1.037$ & $\mathrm{p}_{(\mathrm{MC})}=1.000 \mathrm{NS}$ \\
\hline
\end{tabular}

${ }^{a}$ :Outcome is not mutually exclusive, n: number, df: degree of freedom, MW: Mann-Whitney U test, MC: Monte Carlo significance, NS: non significant difference, *: significant. 


\section{Discussion}

Theophylline is an important cause of intoxication with significant morbidity and mortality due to its narrow therapeutic index (Raymond, 2010). Theophylline intoxication may be acute, acute on therapeutic or chronic (Henry and Minton, 2011). Both intentional and accidental toxicity are common due to its wide availability (Lim et al., 2005).

This prospective cross sectional study of acute theophylline intoxication was designed to clarify the effectiveness of ECG examination to predict outcomes of theophylline poisoning (mortality, ICU admission, need for mechanical ventilation and hemodialysis). In order to achieve this target, sociodemographic, toxicologic, clinical data and major outcomes were analyzed against ECG findings in theophylline poisoned patients.

The main findings of this research confirmed that the mean age, gender, residence, route $\&$ mode of poisoning and clinical data were more or less in agreement with many previous observations in majority of centers in Egypt and across the world (Shannon, 1999; Shannon, 2000; Borkan, 2002; Kumar and Moses, 2004; Shannon, 2007; Shannon, 2008; Tesfaye et al., 2008; National Toxicology Program, 2010; Mohammed, 2011; Yip et al., 2011; ElHawary, 2014).

In the present study, electrocardiographic examination revealed sinus tachycardia, prolonged QTc, upsloping ST segment, biphasic $\mathrm{T}$ wave and premature ventricular contractions. Worldwide and over time, limited comparable researches have described parallel ECG changes in theophylline toxicity. The particular mechanism of such ECG changes is not well known. However, these changes may be caused by increased circulating catecholamines and/or to direct cardiac adenosine receptors antagonism (Kolander et al., 1989; Kumar, 2004; Hoffman, 2006; Shannon, 2007; Lionte et al., 2012).

Grading of electrocardiographic changes was not significantly associated with any of the sociodemographic data, or prehospitalization period. While, both theophylline poisoning severity and theophylline level registered significant statistical association with grading of ECG changes. A result supported by Hoffman (2006) who supposed that sinus tachycardia is nearly seen in all cases with acute theophylline toxicity. At higher serum theophylline levels, more severe atrial and ventricular dysrhythmias including multifocal atrial tachycardia, atrial fibrillation, premature ventricular contractions, and ventricular tachycardia, can occur. He believed that occurrence of such dysrhythmias can determine poisoning severity and mostly appeared at serum level greater than $80 \mathrm{mg} / \mathrm{L}$ in acute overdoses.

In the current study, secondary to association between grading of ECG changes and theophylline poisoning severity it was anticipated to find significant statistical association between grading of ECG changes and major outcome particularly ICU admission and need for hemodialysis. Where, seven patients out of the eight ICU admitted patients registered severe grade of ECG changes. All of the hemodialysed patients recorded severe grade of ECG changes. Moreover, the dead patient who was admitted to ICU and underwent hemodialysis documented severe grade of ECG changes.

However, it was striking to find that, the patient who required intubation and mechanical ventilation assistance showed moderate grade of ECG changes. A finding that point to and support absence of association between grading of ECG changes 
and need for intubation and mechanical ventilation assistance.

Nevertheless, Kolander et al. (1989) described a decrease in both sinoarterial conduction time and His-Purkinje conduction interval. In addition, $\mathrm{T}$ wave inversion and prolongation of QT interval were described in severe theophylline toxicity patients. These changes might be attributed to either direct action of theophylline on the heart (adenosine receptors) or associated increase in the sympathetic tone. However, the usual tachycardia associated with theophylline toxicity might mask these possible ECG changes.

Consequently, the results obtained in the current study pointed to absent significant statistical association between QTc interval and any of sociodemographic, toxicologic and clinical data. Subsequently, mortality and major outcome events (ICU admission, need for mechanical ventilation and hemodialysis) were not statistically associated to QTc interval.

Theophylline as a member of methylxanthines has positive chronotropic and inotropic effects. Either as a result of excessive circulating catecholamines, or myocardial sensitization secondary to theophylline mediated increased second-messenger activity, the extreme inotropic and chronotropic effects cause dysrhythmias (Lionte et al., 2012). High theophylline concentrations (more than 10 $\mathrm{mg} / \mathrm{L}$ ) associated with inhibition of phosphodiesterase and increases in cAMP may result in increased influx of calcium. At higher concentrations (more than $100 \mathrm{mg} / \mathrm{L}$ ), sequestration of calcium by the sarcoplasmic reticulum is impaired (Boushey, 2011). At much higher concentrations, theophylline blocks fast $\mathrm{Na}+$ channels in the myocardium, with a depression of depolarization, and slowing of conduction velocity, manifested on ECG with prolonged PR, QRS, and QTc intervals (Murphy et al., 2007).
The previous data could explain absence of significant statistical association between QTc interval and any of sociodemographic, toxicologic, clinical data including theophylline poisoning severity, theophylline level and major outcome events. As QT prolongation pharmacologically occurs via slowed recovery from inactivation of $\mathrm{Na}+$ channels, delayed inactivation of $\mathrm{Na}+$ channels, and $\mathrm{K}+$ channel blockade (Manini et al., 2010). Henceforth, very high theophylline concentrations are required to block fast $\mathrm{Na}+$ channels in the myocardium with subsequent significant QTc prolongation. Meanwhile, in the current study only two patients recorded serum theophylline level more than $100 \mathrm{mg} / \mathrm{L}$.

Mortality, ICU admission, need for ventilation and hemodialysis were noticed in patients with prolonged QTc interval rather than in patients with a normal QTc interval. However, no significant statistical association was perceived between QTc interval and any of them. Thereafter, a larger sample size with more severe cases might be much more likely to signify association between QTc interval with clinical data and major outcome events.

Remarkably, little is known about ECG as predictor of theophylline intoxication outcome. This is the first study to authors' knowledge evaluating ECG to predict mortality and major outcome events in acute theophylline poisoned patients. Contradictory results about both age and peak serum theophylline concentrations as predictors for development of major toxic effects were suggested by many authors.

Shannon (1999) found no significant association between age and development of major toxic effects in acute theophylline toxicity. Hence, age can be considered as a poor prognostic factor in acute theophylline toxicity (Shannon, 2007). Contradictory to this opinion, Sessler (1990) and Shannon \& Lovejoy (1990) proved patient age as a more sensitive predictor of major toxicity than peak 
serum theophylline concentration in cases of chronic overmedication.

On the other hand, Shannon and Perry (2005) supposed that, high-risk patients could be identified using peak serum theophylline concentration in acute theophylline intoxication. While, there is a striking lack of correlation of peak serum theophylline concentrations with the clinical course for those with chronic theophylline toxicity. Such conflicting results make this study rational to find a theophylline toxicity predictor that reflect the clinical condition of the patient whether this patient is acutely or chronically exposed to theophylline toxicity.

From this study, it could be concluded that, in theophylline intoxicated patients, QTc interval alone is not a predictor for either mortality or major outcome. In the same time, grades of ECG changes could be considered as good predictor for ICU admission and need for hemodialysis.

It is recommended to consider cardiologic consultation for grading of ECG changes to help young toxicologists to identify critical cases of theophylline toxicity during initial assessment in emergency departments (EDs). Theophylline intoxicated patients who are presented by severe ECG changes should be admitted in ICU as high risk patients considered for hemodialysis. Further researches to investigate QTc interval as a predictor of both mortality and major outcome in theophylline toxicity are required.

The principal limitation of the current study is its small sample size precipitated by small number of theophylline intoxicated patients presented to Poison Control Unit, Emergency Hospital, Tanta University. Moreover, absence of chronic exposed theophylline intoxicated patients who require further investigation.

\section{References}

Amin, R.; Alyasin, S.; Rahmani, G. (2003): "Theophylline induced alteration in serum electrolytes and uric acid of asthmatic children". Iranian Journal of Asthma Allergy and Immunology, 2: 3137.

Borkan, S. (2002): "Extracorporeal therapies for acute intoxications". Crit. Care Clin. J., 18:393-420.

Boushey, H. (2011): Drugs used in asthma. In: Basic and Clinical Pharmacology. Katzung B, Masters S, Trevor (Eds.). $11^{\text {th }}$ edition. McGraw Hill: London; P.P. 339-356.

El-Hawary, A.E. (2014): Predictors of acute theophylline toxicity outcomes. Master thesis in Forensic Medicine and Clinical Toxicology, Faculty of Medicine, Tanta University.

Field, A. (2006): Regression. In: Discovering Statistics Using SPSS. Field A (Ed). $2^{\text {nd }}$ ed. SAGE Publications Ltd, London, California, New Delhi, P.P. 143-217.

Henry, J.; Minton, N. (2011): "Treatment of theophylline overdose". American Journal of Emergency Medicine, 14:606.

Hoffman, R. (2006): Methylxanthines and selective B2 adrenergic agonist. In: Goldfrank's Toxicological Emergencies. Flomenbaum N, Goldfrank L, Hoffman $\mathrm{R}$, Howland $\mathrm{M}$, Lewin $\mathrm{N}$, Nelson L. (Eds.). $8^{\text {th }}$ edition. McGrw-Hill: London. P.P. 989-1004.

Jonckheere, A.R. (1954a): "A distributionfree k-sample test against ordered alternatives". Biometrica, 41:S. 133-145.

Jonckheere, A.R. (1954b): "A test of significance for the relation between $\mathrm{m}$ rankings and $\mathrm{k}$ ranked categories". British Journal of Statistical Psychology, 7: S. 93-100. 
Kolander, S.A.; Nydegger, C.C.; Porter, R.S. (1989): "T wave inversion associated with severe theophylline toxicity". Chest J., 96: 429-431.

Kelly, A.M.; Nicholl, J.; Turner, J. (2002): "Determining the most effective level of TRISS-derived probability of survival for use as an audit filter". Emerg. Med. J., 14:146-152.

Kumar, T. (2004): "Acute respiratory infection with CNS excitation symptoms-consider theophylline overdosage". Indian Pediatrics Journal, 41:1066-1067.

Kumar, T.; Moses, P.D. (2004): "Acute Respiratory Infection with CNS Excitation Symptoms-Consider Theophylline Over- Dosage". Indian Pediatr. J., 41:1066-1067.

Lim, S.; Tan, S.; Tai, D.; et al. (2005): "Successful treatment of theophylline toxicity with continuous venovenous hemofiltration". Critical Care and Shock Journal, 8: 96-97.

Lionte, C.; Bologa, C.; Sorodoc, L. (2012): Toxic and drug-induced changes of the electrocardiogram, advances in electrocardiograms - clinical applications, $\mathrm{PhD}$. Richard Millis (Ed.), ISBN: 978-953-307-902-8, In Tech, Available from: http://www.intechopen.com/books/advan ces-in- electrocardiograms-clinicalapplications/toxic-and-drug-inducedchanges-of-electrocardiogram.

Manini, A.F.; Nelson, L.S.; Skolnick, A.H.; et al. (2010): "Electrocardiographic predictors of adverse cardiovascular events in suspected poisoning". J. Med. Toxicol., 6:106-115.

Mohammed, S.S. (2011): Retrospective study of acute theophylline intoxicated cases admitted to poison control center-Ain Shams University. Master thesis in Forensic Medicine and Clinical
Toxicology, Faculty of Medicine, Ain Shams University.

Murphy, N.G; Benowitz, N.L. and Goldschlager, N. (2007): Cardiovascular toxicology. In: Haddad and Winchester's Clinical Management of Poisoning and Drug Overdose. ( $4^{\text {th }}$ Ed.), Shannon, M.W. et al. (Eds.), Saunders Elsevier, ISBN 978-0-7216-0693-4, Philadelphia, USA. P.P. 133-165.

National Toxicology Program (2010): Home $>>$ Testing Information $>>$ Testing status of agents at: http://www.niehs.nih.gov/about/assets/do cs/update_ntp_feb2010_508.pdf

Paul, S.; Saba, M.; Berger, K. (2010): "Theophylline in asthma". Journal of Asthma \& Allergy Educator, 1 (5):180182.

Raymond, Y. (2010): "Home respiratory airway medications: Select toxicities and drug interactions". Quoted from: C:/users/win7/Documents/Downloads/Di scusson- seizures2010. Mht.

Reilly, H. (2008): eMedicine Specialities $>$ Pediatric: Cardiac diseases and Critical care medicine $>$ Toxicology. Quoted References from: http://www.wbmd. com/ services professional. Shtml.

Sessler, C.N. (1990): "Theophylline toxicity: clinical features of 116 consecutive cases". Am. J. Med., 88:567-576.

Shannon, M. (1999): "Life threatening events after theophylline overdose". Arch. Intern. Med. J., 159:989-994.

Shannon, M. (2000): "Theophylline: its rise, demise and resurrection". Clin. Ped. Emerg. Med. J., 1:213-321.

Shannon, M. (2007): Theophylline and caffeine. In Haddad and Winchester Clinical Management of Poisoning and Drug Overdose. Shannon M, Borron S, Burns M (Eds.). $4^{\text {th }}$ edition. Elsevier Inc Company: Philadelphia, P.P. 1035-1049. 
Shannon, M. (2008): Methylxanthines Poisoning. In: Irwin and Rippe's Intensive Care Medicine, Linden HC, Bird BS (Eds.). $6^{\text {th }}$ edition. Lippincott Williams \& Wilkins: Philadelphia, P.1647.

Shannon, M.; Lovejoy, F.H. Jr. (1990): "The influence of age vs peak serum concentration on life-threatening events after chronic theophylline intoxication". Arch. Intern. Med., 150:2045-2048.

Shannon, M. and Perry, E. (2005): Theophylline and other Methyl Xanthine. In: Critical Care Toxicology: Diagnosis and Management of the Critically Poisoned Patients. Brent J. (Eds.). $1^{\text {st }}$ edition. Elsevier Health Sciences, Ch. 40, P.P. 458-464.

Sheehan, M.; Haythorn P. (1976): "Rapid gas chromatographic determination of underivatized theophylline in whole blood”. J. Chromatogr, 117:392-398.
Terpstra, T.J. (1952): “The asymptotic normality and consistency of Kendall's test against trend, when ties are present in one ranking". Indagationes Mathematicae, 14: S. 327-333.

Tesfaye, H.; Prusa, R.; Doupovcová, J. (2008): "Hypokalemia in a suicide attempt of an adolescent girl". Cas. Lek. Cesk. J.,147:333-336.

Wu, J.P.; Wu, Q.; Sun, X.; et al. (2013): "Corticosteroid resistance in chronic obstructive pulmonary disease: new uses of theophylline". Chin. Med. J., 126:965970.

Yip, W.L.; Ng, H.W.; Tse, M.L.; et al., (2011): "An epidemiological study of pediatric poisoning in Hong Kong”. HK J. Pediatric. 16:25-31. 


\section{التغيرات في تخطيط القلب الكهربائي كمتنبئ بالوفاة والنتائج الرئيسية في مرضى التسمم الحاد بالثيوفيللين}

\section{أروة أحمد أبو الفضل و مروة محمد شاهيز ؛ غادة محمد الفزالي:}

قسم الطب الثرعي والسموم الإكلينيكية، قسم الأمراض الباطنة" ـ كلية الطب -جامعة طنطا

لا تز ال سمية الثيوفيللين الحادة أحد أهم أسباب التسمم ذات العو اقب الوخيمة مثنل الاعتلال بشكل ملحوظ

و الوفيات. وقد تضاربت نتائج الأبحاث حول كل من العمر وتركيزات الثيوفيللين كمنتبئات عن تطور الآثار السامة الرئيسية للثيوفيللين. ومع ذللك، لا يُعرف إلا القليل عن تخطيط القلب الكهربائي للتنبؤ بالوفيات و النتائج

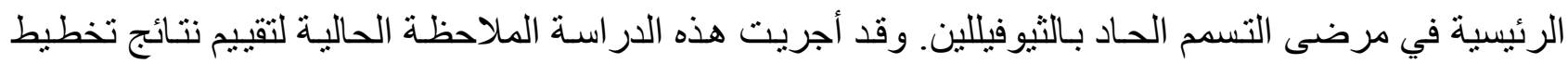
القلب الكهربائي كمتنبئ بالوفيات و النتائج الرئيسية (دخول وحدة العناية المركزة، والحاجة إلى التنفس الصناعي

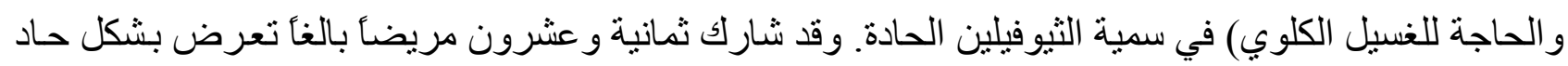

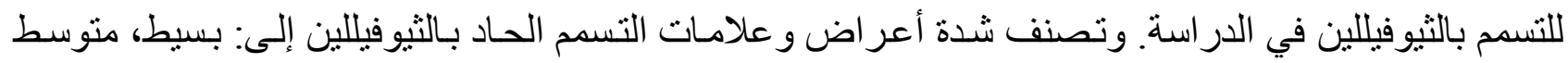
وشديد. تم تسجيل تخطيط القلب الكهربائي (ECG) وتحليله حسب المعدل، الإيقاع، المحور ، والجهد، تشو هات موجة ST و T و وعيوب التوصيل، فاصل PR. و وتصنف التغيرات في تخطيط القلب الناجمة عن التسمح الحاد بـالثيوفيللين إلى: صـغرى، منوسطة وشـيدة. وقدرت الفاصـلة QT المعدلـة (QTc) وفقا لمعادلة

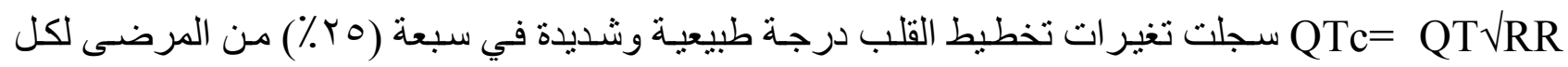

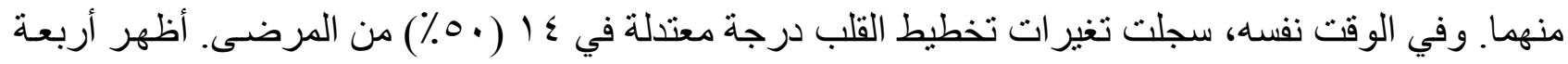

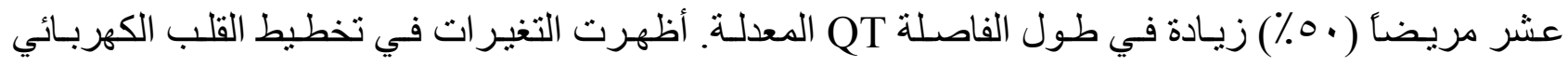
ارتباطأ ذا دلالة إحصائية مع شدة التسمح بالثيوفيللين ومستوى الثيوفيللين و النتائج الرئيسية (دخول وحدة العنايـة

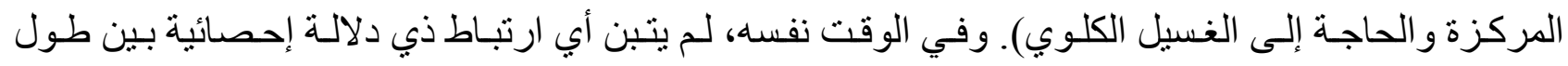

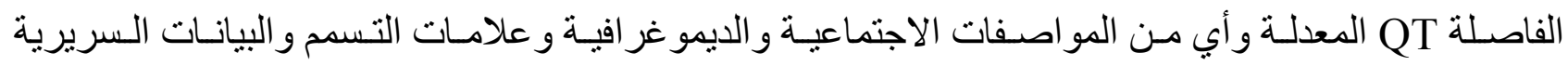
و الوفيات و النتائج الرئيسية. 